\title{
A Functional Analysis of the Cyclophilin Repertoire in the Protozoan Parasite Trypanosoma Cruzi
}

\author{
Alina E. Perrone ${ }^{1}$, Natalia Milduberger ${ }^{1,2}$, Alicia G. Fuchs ${ }^{1,2}$, Patricia L. Bustos ${ }^{1}$ and \\ Jacqueline Bua ${ }^{1,2, *}$ \\ 1 Instituto Nacional de Parasitología “Dr. Mario Fatala Chaben”-ANLIS C.G. Malbrán, Paseo Colón \\ 568-C1282AFF Buenos Aires, Argentina; alinaperrone@yahoo.com.ar (A.E.P.); \\ nmilduberger@gmail.com (N.M.); alicia.fuchs@uai.edu.ar (A.G.F.); pato54mar@yahoo.com.ar (P.L.B.) \\ 2 CAECIHS, Universidad Abierta Interamericana, Av. Montes de Oca 745, $2^{\circ}$ piso, \\ C1270AAH Buenos Aires, Argentina \\ * Correspondence: jacbua@yahoo.com; Tel.: +5411-4331-4010
}

Received: 3 October 2018; Accepted: 29 October 2018; Published: 31 October 2018

\begin{abstract}
Trypanosoma cruzi is the etiological agent of Chagas disease. It affects eight million people worldwide and can be spread by several routes, such as vectorborne transmission in endemic areas and congenitally, and is also important in non-endemic regions such as the United States and Europe due to migration from Latin America. Cyclophilins (CyPs) are proteins with enzymatic peptidyl-prolyl isomerase activity (PPIase), essential for protein folding in vivo. Cyclosporin A (CsA) has a high binding affinity for CyPs and inhibits their PPIase activity. CsA has proved to be a parasiticidal drug on some protozoa, including T. cruzi. In this review, we describe the T. cruzi cyclophilin gene family, that comprises 15 paralogues. Among the proteins isolated by CsA-affinity chromatography, we found orthologues of mammalian CyPs. TcCyP19, as the human $\mathrm{CyPA}$, is secreted to the extracellular environment by all parasite stages and could be part of a complex interplay involving the parasite and the host cell. TcCyP22, an orthologue of mitochondrial CyPD, is involved in the regulation of parasite cell death. Our findings on T. cruzi cyclophilins will allow further characterization of these processes, leading to new insights into the biology, the evolution of metabolic pathways, and novel targets for anti-T. cruzi control.
\end{abstract}

Keywords: Trypanosoma cruzi; Chagas disease; protozoan parasite; cyclosporin A; non-immunosuppressive analogs; trypanocidal compounds; cell death; cyclophilins; TcCyP19; TcCyP22

\section{Introduction to Trypanosoma cruzi Infection and Chagas Disease}

Trypanosoma cruzi is an hemoflagellate parasitic protozoon and the etiological agent of Chagas disease. This parasitosis has epidemiological relevance affecting eight million people, mainly in South America. It is a public health priority in endemic areas because in the long term, 30\% of T. cruzi chronic infected humans will develop serious and irreversible complications due by parasite invasion of muscles and autonomic peripheral nervous system. There are 30,000 new reported cases of Chagas each year in the Americas and 14,000 people die as a result of the disease, while more than 70 million people live in areas where there is high-risk of transmission [1]. This Kinetoplastid unicellular parasite circulates between mammalian hosts and insect vectors, which include a variety of species of Reduviidae (blood-sucking insects also known as kissing bugs), widely distributed from Southern United States to Argentina [2,3]. T. cruzi can be transmitted through other routes than vectorial spread, as mother to child transmission during pregnancy, and with less epidemiological impact, the parasite can be transmitted through blood transfusions, organ transplants, and oral routes [4]. 
Politics in public health to control Chagas disease were successful, considering that the vector transmission of T. cruzi has been interrupted in 17 out of 21 affected countries in the Americas. Additionally blood to be transfused is almost universally screened in blood banks [5]. Now, the main challenge is to maintain the parasite control achievements so far and prevent an actual main route of transmission: the congenital Chagas disease. A baby born to a mother infected with T. cruzi has between $2-10 \%$ chance of contracting this infection during gestation and birth $[6,7]$.

The maternal-child T. cruzi infection has a growing importance in endemic area, since around 1.1 million women of child-bearing age in the region are infected with the T. cruzi parasite, and almost 9000 babies are born each year infected with T. cruzi, accounting for 30\% of all new infections [1,7]. The non-vectorial T. cruzi transmission also has a conspicuous role in non-endemic countries, in which millions of Latin American immigrants are hosted. The T. cruzi infection has been increasingly detected in USA, with more than 300,000 people infected [8], and in Canada, the Western Pacific countries and Europe, where more than 60,000 infected people have been detected in Spain alone [9,10].

Currently, only benznidazole and nifurtimox are recognized by the World Health Organization as effective drugs for treatment of Chagas disease. Benznidazole produces a clear trypanocidal effect in humans and plays an essential role in primary and secondary prevention. Because of the challenges involved in confirming a cure for Chagas disease, benznidazole's benefit is more readily demonstrated during the acute phase. Every effort should be made to identify and treat patients early, before Chagas disease progresses to an advanced chronic form, especially women of gestational age, considering that when T. cruzi-infected women are treated with benznidazole, congenital transmission is prevented in subsequent births, with a tremendous public health impact since congenital infection is a major transmission route [11].

\section{The T. cruzi Cyclophilin Repertoire}

Trypanosoma cruzi, as most of the organisms studied to date, has a family of ubiquitous and highly conserved proteins named cyclophilins that mediate protein folding events, catalizing the interconversion of the cis and trans isomers of peptidyl-prolyl bonds in peptides and proteins (peptidyl-prolyl cis-trans isomerase (PPIase) activity) [12], an enzymatic activity inhibited by the immunosuppressive undecapeptide Cyclosporin A (CsA) [13]. This cyclic peptide has a conformational polymorphism, given by a dependence of its structure and dynamics on the solution environment, that allows it to more readily move through a lipid bilayer and ensures its membrane permeability, increasing its therapeutic potential [14].

The T. cruzi cyclophilin of $19 \mathrm{kDa}, T c C y P 19$, has a $72 \%$ protein sequence identity with the human CyPA, and shows a high sequence identity with other Trypanosomatids of sanitary importance, as Trypanosoma brucei (90\%) and Leishmania spp. (79-81\%) [15]. Using the protein sequence of the archetypal cyclophilin TcCyP19 we have searched sequence identities through the Blast Program [16] in the available databases, and found 15 unique T. cruzi cyclophilin paralogues ranging from 19-110 kDa, some of them with predicted subcellular localization signals. Bioinformatic analysis established that each $T c$ CyP has a unique cyclophilin-like domain, which displays the crucial amino acid residues for PPIase activity, and most of the components of this parasite CyP family show the tryptophan residue essential for CsA binding [17].

Seven T. cruzi cyclophilin gene family members are transcribed to mRNA: TcCyPs of 19, 20, 21, 22, 25, 28, and $40 \mathrm{kDa}$. DNA hybridizations performed with labelled cDNAs revealed these CyPs were organized as a single copy gene in the T. cruzi DNA haploid genome and bound to two different chromosomal bands. Only five T. cruzi cyclophilins were found as expressed proteins: TcCyP19, TcCyP22, TcCyP28 and TcCyP40 were isolated by CsA-affinity chromatography [17] and one cyclophilin of $21 \mathrm{kDa}(\mathrm{TcCyP} 21)$ could only be detected by immunoblotting assays on a membrane-enriched fraction, as it was found to be a low-abundance protein [18]. Orthologues to the human cyclophilin hCyP40 [19], found in Hsp90-containing protein complexes, have also been found in the genomes of T. cruzi, and Leishmania spp. This type of cyclophilin contains two signature motifs, the C-terminal 
three tetratricopeptide repeats (TPRs) [20], involved in protein-protein interaction and the N-terminal cyclophilin-like domain. The TPRs hydrophobic motif are the interaction surfaces necessary for binding to Hsp90 [21]. It was reported that human CyP-40 had a weak affinity CsA since a histidine $(\mathrm{H})$ residue replaced a tryptophan $(\mathrm{W})$, critical for its binding. The $\mathrm{W}$ is highly conserved in other cyclophilins with high affinity for CsA. However, parasitic protozoan cyclophilins of $40 \mathrm{kDa}$ TcCyP40 and Leishmania CyP40 could be isolated by CsA affinity chromatography $[17,22]$.

The secretion of cytosolic cyclophilins to the extracellular space has been described in human cells, and other organisms [23]. Parasite orthologues of hCyPA have also been localized to cytosol and secreted to the surrounding enviroment, like TbCyP19 in Trypanosoma brucei, T. evansi, T. congolense, T. vivax [24], TgCyP19 in Toxoplasma gondii [25], and TcCyP19 in T. cruzi [26]. These trypanosomatid cytosolic cyclophilins present two consensus sequences: Asn-X-Thr and Asn-X-Ser in which the asparagine (Asn 81 and 121) or the serine/threonine (Thr 83 and Ser 123) residues of these motifs could be $\mathrm{N}$-linked or $\mathrm{O}$-linked glycosylated, where they would contribute to their transit through the endoplasmic reticulum (ER) [24]. However, in the first 40 residues of hCyPA orthologues in kinetoplastids, compared in Figure 1, no classical signal peptide could be predicted by internet resources as iPsort, wolfpsort, SecretomeP 2.0 [27], nor Signal P. It is known that secretory proteins not transported through the classical ER-Golgi secretory pathway are secreted through unconventional mechanisms in the absence of an ER signal sequence, such as lysine acetylation or other posttranslational modifications [28].

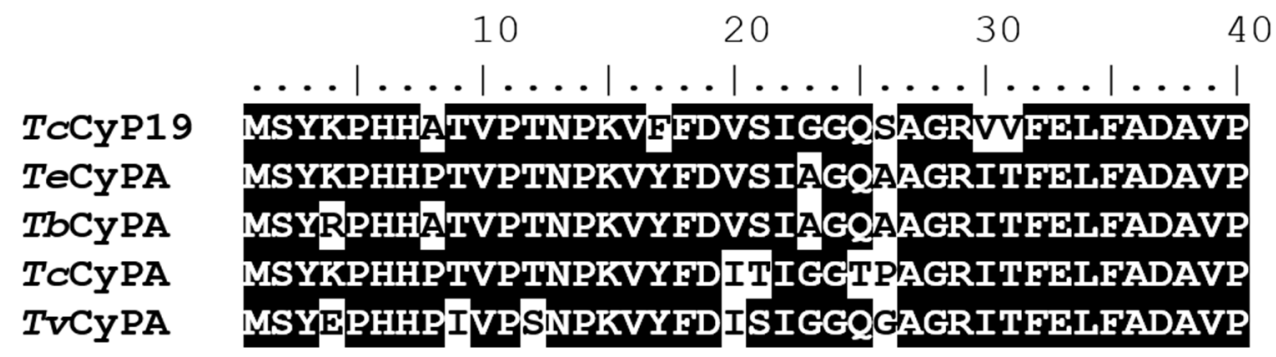

Figure 1. Secreted Kinetoplastid cyclophilins protein sequences. The first 40 amino acid residues of T. cruzi cyclophilin 19 (Acc No. AF191832), were aligned with the protein sequences of T. evansi (TeСyPA; Acc No. ABI20435), T. brucei CyPA (TbCyPA; Acc No. U68270), T. congolense (TcCyPA; Acc No. U68268), T. vivax CyPA (TvCyPA; Acc No. U68269). Identical amino acids respect to the TcCyP19 protein sequence are shadowed.

\section{Cyclosporin A as Trypanocidal Agent}

Since the immunosuppressive drug CsA and cyclosporin derivatives with reduced or non-immunosuppressive properties were reported as parasiticidal against Leishmania tropica [29], Schistosoma mansoni [30] and Plasmodium falciparum [31], parasite cyclophilins received attention as attractive potential drug targets. The anti-parasitic activity of CsA has been demonstrated in numerous protozoan and helminth parasites, reviewed in [32-35]. CsA has demonstrated a similar micromolar range of parasiticidal activity on $T$. cruzi parasites $\left(\mathrm{IC}_{50}=5.9 \mu \mathrm{M}\right)$ [36] compared to benznidazole ( $\mathrm{IC}_{50}$ $=10.0 \mu \mathrm{M})$ for CL Brener epimastigotes [37] and Nifurtimox (Colonia, Germany) $\left(\mathrm{IC}_{50}=3-5 \mu \mathrm{M}\right)$ on several reference strains and isolates [38].

However, in experimental mice models the effects of CsA showed an exacerbation of the T. cruzi infection due to its immunosuppressive properties [39]. Since CsA could not be considered a trypanocidal drug in vivo, we searched synthetic CsA modified compounds, which were non-immunosuppressive CsA analogs, to test if they exerted any trypanocidal activity. We got several compounds from the group of CsA analogs with non-immunosupressive activity available, through generous gifts from Dr. Hosrt Zahner (Institute of Parasitology, Justus-Liebig-University Giessen, Giessen, Germany) and Dr. Ronald Wenger (Institute of Physiology, University of Zürich-Irchel, Zürich, Switzerland) originally synthetized by Novartis (Basel, Switzerland). Of all non-immunosupressive 
CsA derivatives tested, H-7-94 and F-7-62 showed the best parasiticidal effects in micromolar levels against the three forms of the parasite life-cycle, and had non-toxic effects for mammalian cells $[36,40]$.

In an in vivo experimental approach, mice were treated with H-7-94 and F-7-62 CsA analogs before and during the first five days post-infection with T. cruzi bloodstream forms. Drug treated mice survived $(100 \%)$ after parasite challenge and had significant lower parasitemia than non-treated mice control (60\% survival) [36].

Even though the effects of CsA and its derivatives on unicellular parasites of sanitary public heath importance have been evidenced, the current knowledge about the anti-parasitic mechanisms of these drug is rather limited.

\section{The Effects of Cyclosporin A on T. cruzi Cyclophilins}

To characterize enzymatic activity from T. cruzi cyclophilins, recombinant proteins were obtained. All parasite CyPs proved to have PPIase activity (measured as described in Reference [41]). The enzymatic activity was inhibited by CsA and the non-immunosuppressive derivatives H-7-94 and F-7-62, and showed a positive correlation with anti-parasitic effects [36]. Three-dimensional molecular modelling studies on the structure of TcCyP19 complexed with the most effective CsA analogs suggested which putative protein-ligand binding residues were involved. The simulated interactions with the compounds H-7-94 and F-7-62 showed a total potential complex energy that exhibited correlation with the experimental trypanocidal activity observed [42]. The small and cytosolic cyclophilin from humans (hCyPA), and those from parasitic protozoa as Plasmodium falciparum (PfCyP19), Toxoplasma gondii (TgCyP18), Leishmania major (LmCyP19), and Trypanosoma cruzi (TcCyP19) showed a similar CsA inhibition profile of its PPIase activity [36,43,44].

CsA has also been described as an inhibitor of the mitochondrial permeability transition pore (mPTP) in mammals, a pore in the mitochondria which opens under stressful conditions such as $\mathrm{Ca}^{2+}$ overload and oxidative stress, allowing the release of apoptotic-related factors into the cytosol [45]. The only component that has been addressed as indispensable for mPTP opening is the Cyclophilin D (CyPD-Ppif gene) [46]. CsA binds to CyPD, causing a "desensitization" effect and inhibiting mPTP opening [47].

Regarding oxidative stress, CsA specifically inhibited cell death events on T. cruzi parasites under hydrogen peroxide stimulus as mitochondrial membrane depolarization, parasite DNA fragmentation, phosphatidylserine exposure to the external membrane surface, and Annexin V binding, reactive oxygen species production and cytochrome $c$ translocation from mitochondrion to cytosol (Figure 2) [48]. This suggested that CsA would be inhibiting a regulated cell death process in this protozoan parasite, as occurs in mammalian cells by CsA-CyPD binding.

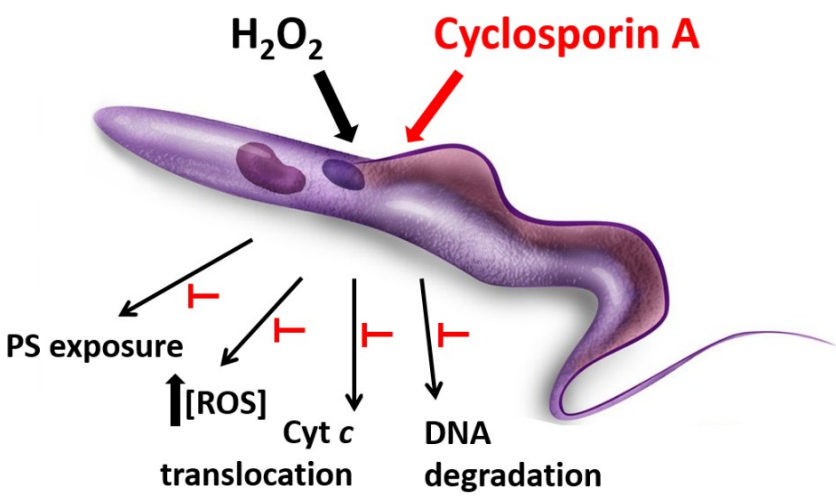

Figure 2. Protective effect of Cyclosporin A against oxidative stress. T. cruzi epimastigotes incubated with $\mathrm{H}_{2} \mathrm{O}_{2}$ exhibit cell death features such as mitochondrial membrane depolarization, parasite DNA fragmentation, phosphatidylserine (PS) exposure to the external membrane surface, an increase in reactive oxygen species production and cytochrome $\mathrm{c}$ translocation from mitochondrion to cytosol. All these events do not occur when parasites are pre-treated with $1 \mu \mathrm{M}$ Cyclosporin A. 
mPTP opening had not been previously described for a parasitic protozoan and it has been only suggested for Leishmania parasites [49]. Based on our previous results on oxidative stress damage, we investigated whether this cell death mechanism through mPTP opening may occur in T. cruzi. Our results demonstrated the presence of the MPTP in the parasite. Experiments were performed with a highly selective indicator of $\mathrm{MPTP}$ opening as the fluorescent dye calcein-AM co-loaded with $\mathrm{CoCl}_{2}$ as a quencher. CsA incubation showed increased calcein retention in the mitochondrion, $(60 \%)$ and when other mPTP inhibitors (described for mammalian cells) were added, as Bongkrekic acid and ADP, up to $86 \%$ calcein retention was achieved, suggesting the existence of a mPTP-like pore in T. cruzi parasites, with similar proteins to the mammalian mitochondrial pore, and among them, a mitochondrial cyclophilin orthologue to CyPD [48].

The observation that CsA inhibited some cell death events in T. cruzi and other protozoan parasites allowed a better understanding of this pathway. However, further research needs to be done to identify all the effector molecules involved in this process.

\section{Functional Features of T. cruzi Peptidyl-Prolyl cis-trans Isomerases}

The Trypanosoma cruzi life cycle starts in a mammal reservoir and a triatomine bug serves as the vector. In mammals, the bloodstream and infectious forms are called trypomastigotes, and must cross a network of membrane proteins to invade the host cells. The replicative and intracellular form of the parasite is the amastigote, and it can persist for a long time in different organs establishing a chronic infection.

The parasite cyclophilin of $19 \mathrm{kDa}$ has been involved as a key mediator, enhancing parasite survival through the gastrointestinal tract of the reduviid vector. The novel parasite pathway proposed is that the secreted TcCyP19 binds and neutralizes an insect antimicrobial lytic peptide, activating calcineurin intracellular signaling [26]. Besides, the protein expression and mRNA transcription of the T. cruzi cyclophilin of $19 \mathrm{kDa}$ were twofold higher in those parasites populations who were in vitro induced to be resistant to the parasiticidal drug benznidazol. The chaperoning activity of the overexpressed TcCyP19 could be associated with the activity of enzymes with antioxidant defense conferring the parasite resistance to benznidazol [50].

TcCyP19 is abundantly expressed in T. cruzi, and interacts with mammalian cells, association that could be confirmed by flow cytometry, and furthermore, this protein was found inside VERO cells, a process that was partially inhibited by CsA. The incubation of cyclophilin TcCyP19 with VERO cells restrained the parasite penetration, and again, pre-incubation of TcCyP19 with its inhibitor CsA or specific polyclonal antibodies recovered the percentage of parasite-infected cells in control experiments. The inhibitory penetration effect of $T c \mathrm{CyP} 19$ cyclophilin suggests a protective role of this protein to assure the survival of the infected tissue and allow parasite persistence (Figure 3) (unpublished results). TcCyP19 cyclophilin is suspected to have a very interesting role in the parasite-host relationship, so we intended to study its mammalian target protein using different approaches as pull down, immunoprecipitation, and protein crosslinkers, but did not find any substrates in these assays, suggesting a transient protein-protein interaction, as it has also been observed for Mycobacterium tuberculosis [51].

Regarding the CsA cytoprotective effects observed in T. cruzi that undergo oxidative stress, we proposed the existence of a mitochondrial transition pore-like in the parasite, and searched for an homologue of the mammalian CyPD in the parasite as target. TcCyP22 protein, which could be isolated by CsA affinity chromatography [17], showed a putative mitochondrial localization, and its localization to mitochondria was confirmed in the three stages of the parasite life cycle [52]. Oxidative stress was induced in overexpressing TcCyP22 parasites and an enhanced loss of mitochondrial membrane potential and cell viability were significantly different from control parasites, defining an homologue of CyPD for the first time in a protozoan parasite, and the involvement of this protein in T. cruzi regulated cell death [52,53].

Other parasitic protozoan small cyclophilins have been involved in several cell functions as L. braziliensis and L. infantum resistance to anti-parasitic drugs [54], aggregation-disaggregation of proteins in Leishmania donovani $[55,56]$, and the interesting fact that Toxoplasma gondii ToCyP18 binds the CCR5 receptor blocking HIV infection on human T cells [57]. Regarding larger protozoan cyclophilins, mutants of 
L. donovani CyP40 showed a defect in its virulence, as parasites fail to establish an intracellular infection [58], and upregulates several stress proteins, probably to compensate for the lack of the CyP40 [59].
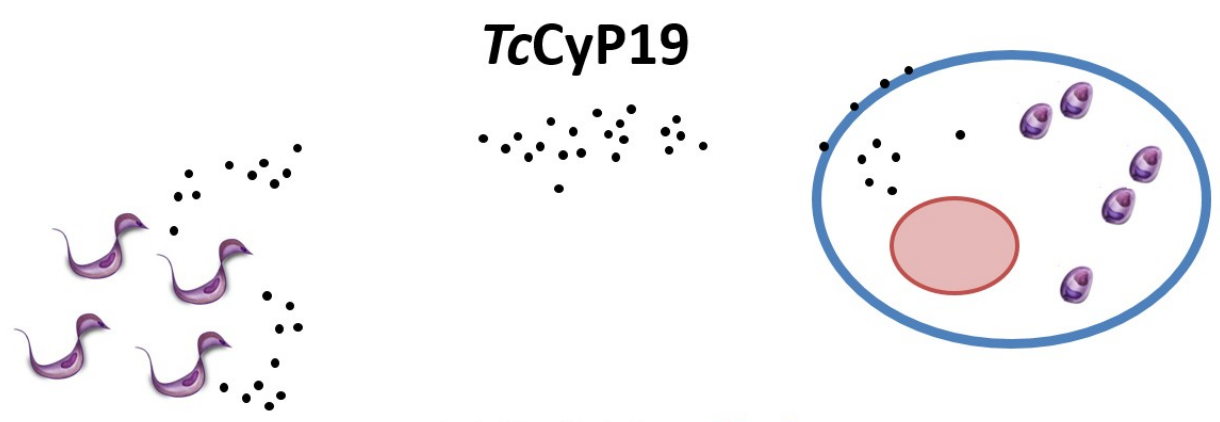

(A)

\section{TcCyP19 + CsA}
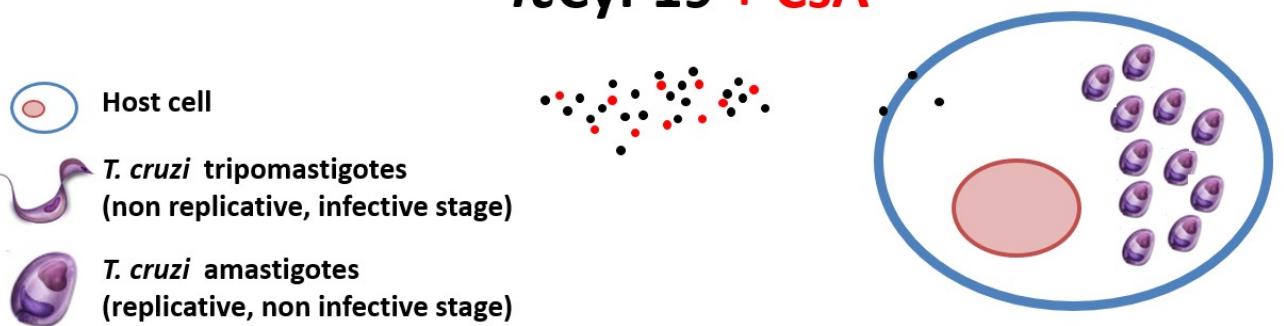

(B)

Figure 3. $\mathrm{TcCyP} 19$ is abundantly expressed in T. cruzi, and interacts with mammalian cells, a process that was partially inhibited by Cyclosporin A (CsA). The pre-incubation of cyclophilin TcCyP19 with VERO cells restrained the parasite penetration (A), and again, pre-incubation of TcCyP19 with its inhibitor CsA or specific polyclonal antibodies recovered the percentage of parasite infected cells in control experiments (B). The inhibitory penetration effect of TcCyP19 cyclophilin suggests a protective role of this protein to assure the survival of the infected tissue and allow parasite persistence.

\section{Concluding Remarks}

Though molecular aspects have been extensively described for cyclophilins in diverse parasites affecting humans such as Plasmodium falciparum [43,60], Toxoplasma gondii [44,61], Leishmania major [62], L. donovani [63], Trypanosoma brucei [24] and T. cruzi [17], the functional role of many expressed parasitic unicellular cyclophilins remains unknown, requiring further investigation.

The final assessment of the biological functions of $T$. cruzi cyclophilins will require successful gene knock out and overexpression, currently ongoing.

Author Contributions: A.E.P. and J.B. wrote the manuscript with support from N.M., A.G.F. and P.L.B. J.B. conceived the original idea and supervised the project.

Funding: This research was funded by PIP 2014-0125, PICT 2016-2693, FOCANLIS 2015, CAECIHS-UAI.

Conflicts of Interest: The authors declare no conflict of interest. The funders had no role in the design of the study; in the collection, analyses, or interpretation of data; in the writing of the manuscript, or in the decision to publish the results.

\section{References}

1. World Health Organization. Epidemiology; World Health Organization: Geneva, Switzerland. Available online: http:/ / www.who.int/chagas/epidemiology/en/ (accessed on 1 October 2018).

2. Yamagata, Y.; Nakagawa, J. Control of Chagas Disease. Adv. Parasitol. 2006, 61, 129-165. [PubMed]

3. Bern, C.; Kjos, S.; Yabsley, M.J.; Montgomery, S.P. Trypanosoma cruzi and Chagas' Disease in the United States. Clin. Microbiol. Rev. 2011, 24, 655-681. [CrossRef] [PubMed]

4. Pérez-Molina, J.A.; Molina, I. Chagas disease. Lancet 2018, 391, 82-94. [CrossRef] 
5. Picado, A.; Cruz, I.; Redard-Jacot, M.; Schijman, A.G.; Torrico, F.; Sosa-Estani, S.; Katz, Z.; Ndung'u, J.M. The burden of congenital Chagas disease and implementation of molecular diagnostic tools in Latin America. BMJ Glob. Health 2018, 3, e001069. [CrossRef] [PubMed]

6. Bua, J.; Volta, B.J.; Perrone, A.E.; Scollo, K.; Velázquez, E.B.; Ruiz, A.M.; De Rissio, A.M.; Cardoni, R.L. How to Improve the Early Diagnosis of Trypanosoma cruzi Infection: Relationship between Validated Conventional Diagnosis and Quantitative DNA Amplification in Congenitally Infected Children. PLoS Negl. Trop. Dis. 2013, 7, 12-14. [CrossRef] [PubMed]

7. Carlier, Y.; Truyens, C. Congenital Chagas disease as an ecological model of interactions between Trypanosoma cruzi parasites, pregnant women, placenta and fetuses. Acta Trop. 2015, 151, 103-115. [CrossRef] [PubMed]

8. Hsu, R.C.; Burak, J.; Tiwari, S.; Chakraborti, C.; Sander, G.E. Chagas Cardiomyopathy in New Orleans and the Southeastern United States. Ochsner J. 2016, 16, 304-308. [PubMed]

9. Rodriguez-Guardado, A.; González, M.L.; Rodriguez, M.; Flores-Chavez, M.; Boga, J.A.; Gascon, J. Trypanosoma cruzi infection in a Spanish liver transplant recipient. Clin. Microbiol. Infect. 2015, 21, 687.e1-687.e3. [CrossRef] [PubMed]

10. Soriano-Arandes, A.; Angheben, A.; Serre-Delcor, N.; Treviño-Maruri, B.; Gómez i Prat, J.; Jackson, Y. Control and management of congenital Chagas disease in Europe and other non-endemic countries: Current policies and practices. Trop. Med. Int. Health 2016, 21, 590-596. [CrossRef] [PubMed]

11. Kratz, J.M.; Garcia Bournissen, F.; Forsyth, C.J.; Sosa-Estani, S. Clinical and pharmacological profile of benznidazole for treatment of Chagas disease. Expert Rev. Clin. Pharmacol. 2018, 11, 943-957. [CrossRef] [PubMed]

12. Handschumacher, R.; Harding, M.; Rice, J.; Drugge, R. Specific Cytosolic Bidg Protein for Cyclosporin. Science 1984, 226, 544-547. [CrossRef] [PubMed]

13. Takahashi, N.; Hayano, T.; Suzuki, M. Peptidyl-prolyl cis-trans isomerase is the cyclosporin A-binding protein cyclophilin. Nature 1989, 337, 473-475. [CrossRef] [PubMed]

14. Wang, C.K.; Swedberg, J.E.; Harvey, P.J.; Kaas, Q.; Craik, D.J. Conformational Flexibility Is a Determinant of Permeability for Cyclosporin. J. Phys. Chem. B 2018, 122, 2261-2276. [CrossRef] [PubMed]

15. Búa, J.; Åslund, L.; Pereyra, N.; García, G.A.; Bontempi, E.J.; Ruiz, A.M. Characterisation of a cyclophilin isoform in Trypanosoma cruzi. FEMS Microbiol. Lett. 2001, 200, 43-47. [CrossRef]

16. Altschul, S.F.; Gish, W.; Miller, W.; Myers, E.W.; Lipman, D.J. Basic local alignment search tool. J. Mol. Biol. 1990, 215, 403-410. [CrossRef]

17. Potenza, M.; Galat, A.; Minning, T.A.; Ruiz, A.M.; Duran, R.; Tarleton, R.L.; Marín, M.; Fichera, L.E.; Búa, J. Analysis of the Trypanosoma cruzi cyclophilin gene family and identification of Cyclosporin A binding proteins. Parasitology 2006, 132, 867-882. [CrossRef] [PubMed]

18. Bustos, P.L.; Perrone, A.E. Improved Immuno-Detection of a Low-Abundance Cyclophilin Allows the Confirmation of its Expression in a Protozoan Parasite. Immunochem. Immunopathol. 2015, 1, 1-4. [CrossRef]

19. Kieffers, L.J.; Thalhammere, T.; Handschumacher, E. Isolation and Characterization of a 40-kDa Cyclophilin-related Protein. J. Biol. Chem. 1992, 267, 5503-5507.

20. Hoffmann, K.; Kakalis, L.T.; Anderson, K.S.; Armitage, I.M.; Handschumacher, R.E. Expression of Human Cyclophilin-40 and the Effect of the His141 $\rightarrow$ Trp Mutation on Catalysis and Cyclosporin A Binding. Eur. J. Biochem. 1995, 229, 188-193. [CrossRef] [PubMed]

21. Ratajczak, T.; Carrello, A. Cyclophilin 40 (CyP-40), mapping of its hsp90 binding domain and evidence that FKBP52 competes with CyP-40 for hsp90 binding. J. Biol. Chem. 1996, 271, 2961-2965. [CrossRef] [PubMed]

22. Yau, W.L.; Blisnick, T.; Taly, J.F.; Helmer-Citterich, M.; Schiene-Fischer, C.; Leclercq, O.; Li, J.; Schmidt-Arras, D.; Morales, M.A.; Notredame, C.; et al. Cyclosporin A treatment of Leishmania donovani reveals stage-specific functions of cyclophilins in parasite proliferation and viability. PLoS Negl. Trop. Dis. 2010, 4, e729. [CrossRef] [PubMed]

23. Peng, H.; Vijayakumar, S.; Schiene-Fischer, C.; Li, H.; Purkerson, J.M.; Malesevic, M.; Liebscher, J.; Al-Awqati, Q.; Schwartz, G.J. Secreted cyclophilin A, a peptidylprolyl cis-trans isomerase, mediates matrix assembly of Hensin, a protein implicated in epithelial differentiation. J. Biol. Chem. 2009, 284, 6465-6475. [CrossRef] [PubMed]

24. Pellé, R.; McOdimba, F.; Chuma, F.; Wasawo, D.; Pearson, T.W.; Murphy, N.B. The African trypanosome cyclophilin A homologue contains unusual conserved central and N-terminal domains and is developmentally regulated. Gene 2002, 290, 181-191. [CrossRef] 
25. Aliberti, J.; Valenzuela, J.G.; Carruthers, V.B.; Hieny, S.; Andersen, J.; Charest, H.; Sousa, C.R.; Fairlamb, A.; Ribeiro, J.M.; Sher, A. Molecular mimicry of a CCR5 binding-domain in the microbial activation of dendritic cells. Nat. Immunol. 2003, 4, 485-490. [CrossRef] [PubMed]

26. Kulkarni, M.M.; Karafova, A.; Kamysz, W.; Schenkman, S.; Pelle, R.; McGwire, B.S. Secreted trypanosome cyclophilin inactivates lytic insect defense peptides and induces parasite calcineurin activation and infectivity. J. Biol. Chem. 2013, 288, 8772-8784. [CrossRef] [PubMed]

27. Bendtsen, J.D.; Jensen, L.J.; Blom, N.; Von Heijne, G.; Brunak, S. Feature-based prediction of non-classical and leaderless protein secretion. Protein Eng. Des. Sel. 2004, 17, 349-356. [CrossRef] [PubMed]

28. Hoffmann, H.; Schiene-Fischer, C. Functional aspects of extracellular cyclophilins. Biol. Chem. 2014, 395, 721-735. [CrossRef] [PubMed]

29. Solbach, W.; Forberg, K.; Kammerer, E.; Bogdan, C.; Röllinghoff, M. Suppressive effect of cyclosporin A on the development of Leishmania tropica-induced lesions in genetically susceptible BALB/c mice. J. Immunol. 1986, 137, 702-707. [PubMed]

30. Chappell, L.H.; Thomson, A.W.; Barker, G.C.; Smith, S.W.G. Dosage, timing, and route of administration of cyclosporin A and nonimmunosuppressive derivatives of dihydrocyclosporin A and cyclosporin C against Schistosoma mansoni in vivo and in vitro. Antimicrob. Agents Chemother. 1987, 31, 1567-1571. [CrossRef] [PubMed]

31. Bell, A.; Wernli, B.; Franklin, R.M. Roles of peptidyl-prolyl CIS-trans isomerase and calcineurin in the mechanisms of antimalarial action of cyclosporin a, FK506, and rapamycin. Biochem. Pharmacol. 1994, 48, 495-503. [CrossRef]

32. Galat, A.; Bua, J. Molecular aspects of cyclophilins mediating therapeutic actions of their ligands. Cell. Mol. Life Sci. 2010, 67, 3467-3488. [CrossRef] [PubMed]

33. Page, A.P.; Kumar, S.; Carlow, C.K.S. Parasite cyclophilins and antiparasite activity of cyclosporin A. Parasitol. Today 1995, 11, 385-388. [CrossRef]

34. Bell, A.; Monaghan, P.; Page, A.P. Peptidyl-prolyl cis-trans isomerases (immunophilins) and their roles in parasite biochemistry, host-parasite interaction and antiparasitic drug action. Int. J. Parasitol. 2006, 36, 261-276. [CrossRef] [PubMed]

35. Chappell, L.H.; Wastling, J.M. Cyclosporin A: Antiparasite drug, modulator of the host-parasite relationship and immunosuppressant. Parasitology 1992, 105, S25-S40. [CrossRef] [PubMed]

36. Bua, J.; Fichera, L.E.; Fuchs, A.G.; Potenza, M.; Dubin, M.; Wenger, R.O.; Moretti, G.; Scabone, C.M.; Ruiz, A.M. Anti-Trypanosoma cruzi effects of cyclosporin A derivatives: Possible role of a P-glycoprotein and parasite cyclophilins. Parasitology 2008, 135, 217-228. [CrossRef] [PubMed]

37. Garavaglia, P.A.; Laverrière, M.; Cannata, J.J.B.; García, G.A. Putative role of the aldo-keto reductase from Trypanosoma cruzi in benznidazole metabolism. Antimicrob. Agents Chemother. 2016, 60, 2664-2670. [CrossRef] [PubMed]

38. Luna-Marín, K.P.; Hernández, I.P.; Rueda, C.M.; Zorro, M.M.; Croft, S.L.; Escobar, P. In vitro susceptibility of Trypanosoma cruzi strains from Santander, Colombia, to hexadecylphosphocholine (miltefosine), nifurtimox and benznidazole. Biomédica 2009, 29, 448-455.

39. McCabe, R.E.; Remington, J.S.; Araujo, F.G. In Vivo and in Vitro Effects of Cyclosporin A on Trypanosoma cruzi. Am. J. Trop. Med. Hyg. 1985, 34, 861-865. [CrossRef] [PubMed]

40. Bua, J.; Ruiz, A.M.; Potenza, M.; Fichera, L.E. In vitro anti-parasitic activity of Cyclosporin A analogs on Trypanosoma cruzi. Bioorg. Med. Chem. Lett. 2004, 14, 4633-4637. [CrossRef] [PubMed]

41. Fischer, G.; Bang, H.; Mech, C. Nachweis einer Enzymkatalyse für die cis-trans-Isomerisierung der Peptidbindung in prolinhaltigen Peptiden. Biomed. Biochim. Acta 1984, 43, 1101-1111. [PubMed]

42. Carraro, R.; Bua, J.; Ruiz, A.; Paulino, M. Modelling and study of cyclosporin A and related compounds in complexes with a Trypanosoma cruzi cyclophilin. J. Mol. Graph. Model. 2007, 26, 48-61. [CrossRef] [PubMed]

43. Berriman, M.; Fairlamb, A.H. Detailed characterization of a cyclophilin from the human malaria parasite Plasmodium falciparum. Biochem. J. 1998, 334, 437-445. [CrossRef] [PubMed]

44. High, K.P. The antimicrobial activities of cyclosporine, FK506, and rapamycin. Transplantation 1994, 57, 1689-1700. [CrossRef] [PubMed]

45. Crompton, M.; Virji, S.; Ward, J.M. Cyclophilin-D binds strongly to complexes of the voltage-dependent anion channel and the adenine nucleotide translocase to form the permeability transition pore. Eur. J. Biochem. 1998, 258, 729-735. [CrossRef] [PubMed] 
46. Baines, C.P.; Kaiser, R.A.; Purcell, N.H.; Blair, N.S.; Osinska, H.; Hambleton, M.A.; Brunskill, E.W.; Sayen, M.R.; Gottlieb, R.A.; Dorn, G.W.; et al. Loss of cyclophilin D reveals a critical role for mitochondrial permeability transition in cell death. Nature 2005, 434, 658-662. [CrossRef] [PubMed]

47. Zhu, C.; Wang, X.; Deinum, J.; Huang, Z.; Gao, J.; Modjtahedi, N.; Neagu, M.R.; Nilsson, M.; Eriksson, P.S.; Hagberg, H.; et al. Cyclophilin A participates in the nuclear translocation of apoptosis-inducing factor in neurons after cerebral hypoxia-ischemia. J. Exp. Med. 2007, 204, 1741-1748. [CrossRef] [PubMed]

48. Bustos, P.L.; Perrone, A.E.; Milduberger, N.; Postan, M.; Bua, J. Oxidative stress damage in the protozoan parasite Trypanosoma cruzi is inhibited by Cyclosporin A. Parasitology 2015, 142, 1024-1032. [CrossRef] [PubMed]

49. Elmahallawy, E.K.; Jiménez-Aranda, A.; Martínez, A.S.; Rodriguez-Granger, J.; Navarro-Alarcón, M.; Gutiérrez-Fernández, J.; Agil, A. Activity of melatonin against Leishmania infantum promastigotes by mitochondrial dependent pathway. Chem. Biol. Interact. 2014, 220, 84-93. [CrossRef] [PubMed]

50. Rêgo, J.V.; Duarte, A.P.; Liarte, D.B.; de Carvalho Sousa, F.; Barreto, H.M.; Bua, J.; Romanha, A.J.; Rádis-Baptista, G.; Murta, S.M.F. Molecular characterization of Cyclophilin (TcCyP19) in Trypanosoma cruzi populations susceptible and resistant to benznidazole. Exp. Parasitol. 2015, 148, 73-80. [CrossRef] [PubMed]

51. Schumacher, A.; Westermann, B.; Osborn, M.; Nordheim, A. The N-terminal signal peptide of the murine cyclophilin mCyP-S1 is required in vivo for ER localization. Eur. J. Cell. Biol. 1994, 63, 182-191. [PubMed]

52. Bustos, P.L.; Volta, B.J.; Perrone, A.E.; Milduberger, N.; Bua, J. A homolog of cyclophilin D is expressed in Trypanosoma cruzi and is involved in the oxidative stress-damage response. Cell Death Discov. 2017, 3, 16092. [CrossRef] [PubMed]

53. Bustos, P.L.; Perrone, A.E.; Milduberger, N.A.; Bua, J. Mitochondrial permeability transition in protozoan parasites: what we learned from Trypanosoma cruzi. Cell Death Dis. 2017, 8, e3057. [CrossRef] [PubMed]

54. Matrangolo, F.S.V.; Liarte, D.B.; Andrade, L.C.; De Melo, M.F.; Andrade, J.M.; Ferreira, R.F.; Santiago, A.S.; Pirovani, C.P.; Silva-Pereira, R.A.; Murta, S.M.F. Comparative proteomic analysis of antimony-resistant and-susceptible Leishmania braziliensis and Leishmania infantum chagasi lines. Mol. Biochem. Parasitol. 2013, 190, 63-75. [CrossRef] [PubMed]

55. Chakraborty, A.; Das, I.; Datta, R.; Sen, B.; Bhattacharyya, D.; Mandal, C.; Datta, A.K. A single-domain cyclophilin from Leishmania donovani reactivates soluble aggregates of adenosine kinase by isomerase-independent chaperone function. J. Biol. Chem. 2002, 277, 47451-47460. [CrossRef] [PubMed]

56. Mukherjee, D.; Patra, H.; Laskar, A.; Dasgupta, A.; Maiti, N.C.; Datta, A.K. Cyclophilin-mediated reactivation pathway of inactive adenosine kinase aggregates. Arch. Biochem. Biophys. 2013, 537, 82-90. [CrossRef] [PubMed]

57. Golding, H.; Aliberti, J.; King, L.R.; Manischewitz, J.; Andersen, J.; Valenzuela, J.; Landau, N.R.; Sher, A. Inhibition of HIV-1 infection by a CCR5-binding cyclophilin from Toxoplasma gondii. Blood 2003, 102, 3280-3286. [CrossRef] [PubMed]

58. Yau, W.L.; Pescher, P.; Macdonald, A.; Hem, S.; Zander, D.; Retzlaff, S.; Blisnick, T.; Rotureau, B.; Rosenqvist, H.; Wiese, M.; et al. The Leishmania donovani chaperone cyclophilin 40 is essential for intracellular infection independent of its stage-specific phosphorylation status. Mol. Microbiol. 2014, 93, 80-97. [CrossRef] [PubMed]

59. Yau, W.L.; Lambertz, U.; Colineau, L.; Pescher, P.; MacDonald, A.; Zander, D.; Retzlaff, S.; Eick, J.; Reiner, N.E.; Clos, J.; et al. Phenotypic Characterization of a Leishmania donovani Cyclophilin 40 Null Mutant. J. Eukaryot. Microbiol. 2016, 63, 823-833. [CrossRef] [PubMed]

60. Reddy, G.R. Cloning and characterization of a Plasmodium falciparum cyclophilin gene that is stage-specifically expressed. Mol. Biochem. Parasitol. 1995, 73, 111-121. [CrossRef]

61. Krücken, J.; Greif, G.; Von Samson-Himmelstjerna, G. In silico analysis of the cyclophilin repertoire of apicomplexan parasites. Parasit. Vectors 2009, 2, 1-24. [CrossRef] [PubMed]

62. Rascher, C.; Pahl, A.; Pecht, A.; Brune, K.; Solbach, W.; Bang, H. Leishmania major parasites express cyclophilin isoforms with an unusual interaction with calcineurin. Biochem. J. 1998, 334, 659-667. [CrossRef] [PubMed]

63. Dutta, M.; Delhi, P.; Sinha, K.M.; Banerjee, R.; Datta, A.K. Lack of Abundance of Cytoplasmic Cyclosporin A-binding Protein Renders Free-living Leishmania donovani Resistant to Cyclosporin A. J. Biol. Chem. 2001, 276, 19294-19300. [CrossRef] [PubMed]

(C) 2018 by the authors. Licensee MDPI, Basel, Switzerland. This article is an open access article distributed under the terms and conditions of the Creative Commons Attribution (CC BY) license (http:/ / creativecommons.org/licenses/by/4.0/). 